\title{
Effect of Mulch on Soybean (Glycine Max L. Merr.) at Cultivation under Drip Irrigation in the South-east of Kazakhstan
}

\author{
Zh.A. Abdukadirova ${ }^{1}$, M.S. Kurmanbayeva ${ }^{2}$ and Zh.O. Ospanbayev ${ }^{3}$ \\ ${ }^{1}$ Kazakh State Women’s Teacher Training University, ${ }^{2}$ Al-Farabi Kazakh National University, \\ ${ }^{3}$ Kazakh Scientific Research Institute of Agriculture and Plant, \\ http://dx.doi.org/10.13005/bbra/2094
}

(Received: 10 April 2016; accepted: 21 May 2016)

\begin{abstract}
Soybean (Glycine max L. Merr) crops were grown in 2013-2015 to determine effect of drip irrigation in the different variants water levels with using mulch on growth and productivity under conditions of the south-east of Kazakhstan. The use of mulch in agriculture has increased in last years throughout the world. This article presents the outcome of field experiments conducted in the Kazakhstan on the effects of drip irrigation (DI) practices on reproductive stages of soybean. Drip irrigation with or without mulch was adopted for the experimental plots. The most effective way to combat weeds in soybean crops proved to drip irrigation under mulch film, where the number of weeds in the early growing season did not exceed 36-44 units $/ \mathrm{m}^{2}$. Despite the prevailing adverse weather conditions for the growth and development of soybean in the south-east of Kazakhstan, we have received a fairly high yield (42.2 tonnes / ha) on a variant using a mulching film. The results indicated that use mulch under drip irrigation significantly increase plant growth and production soybean. This increase is due to benefits such as increase in soil temperature, reduced weed pressure, moisture conservation, reduction of certain insect pests, higher crop yields, and more efficient use of soil nutrients.
\end{abstract}

Key words: Soybean, Drip irrigation, Mulch, Productivity.

Soybean (Glycine max L.) is an economical and valuable agricultural commodity due to its unique chemical composition. It is one of the world's most important leguminous plants. It is considered as a good source of high quality plant protein and vegetable oil. Given its high concentration of protein (36-48\%), oil (1824\%), and carbohydrate (20\%), soybean is grown in almost all parts of the world for human consumption, industry and animal feed. Besides, diets including soybean have been proposed to reduce risk of major diseases such as breast cancer, cardiovascular disease, osteoporosis, diabetes and obesity. The biochemical composition of soybean seeds affect the quality of various soy

\footnotetext{
* To whom all correspondence should be addressed. E-mail: kurmanbaevakz@mail.ru
}

foods such as soy milk, soy flour, tofu, soy sprouts, soy concentrates and soy isolates. Higher protein content and low oil content are generally desirable characteristics for food users (H. Kirnak et al.,2010).

The need for reduction in water use by agriculture is being advocated globally due to stiffer competition among fresh water users such as industry and the environment. Several suggestions have been made to optimize the use of water for crop production. One of them is that water should be applied to crops when they need it most, that is when shortage of water could lead to significant reduction in yield. This approach is called regulated, pre-planned or deficit irrigation (DI). DI is a means of reducing crop water use while minimizing adverse effects on crop yield. In order to adopt DI, information on the responses of crops to water deficit at various stages is required (Omotayo Adeboye et al., 2015). 
(Irmak, S. et al., 2014) evaluated the relative evaporative losses and water balance components in two soybean Glycine max (L.) Merr. fields under subsurface drip irrigation and center pivot irrigation systems in south-central Nebraska. Evaporation losses were estimated as the difference between measured evapotranspiration and estimated transpiration . Average soil water content in the crop root zone and effective rainfall were estimated using the water balance method.

Soybean (Glycine max) is one of the most important legume crops which fix atmospheric nitrogen in symbiotic association with bacteria through nodules. A study was conducted to investigate the effect of molybdenum and preinoculation of Rhizobium on biological nitrogen fixation and yield of soybean under drip irrigation system. Application of $1 \mathrm{~kg}$ of Mo/ha in association of UPMR020, produced significantly high yield (29.46 g/plant) compared to control which produced only $915 \mathrm{~g} /$ plant, thus indicating the potential of this treatment to be used for soybean with drip irrigation system (Kanaan, Bassam Abdul Jabbar, 2013). The growth and yield potential of soybean and the effects of mulching on desert sand were evaluated in relation to $\mathrm{N}$ accumulation in nodules. The experiment was conducted in concrete framed plots filled with sand obtained from the Dzungar desert or the normal field soil in Shihezi, Xinjiang, China. It was concluded that nitrogen fertilisation improves the nutraceutical properties of soybean, although its effect depends on the activity of the isoflavone biosynthetic pathway and the concurrent extent of seed bulging (Vamerali, T., Barion, G., Hewidy, M., Mosca, G. 2012).

A field experiment conducted during 2009 and 2010 at the research farm of the Indian Agricultural Research Institute, New Delhi to study the performance of soybean as influenced by the intercropping of cereals, viz. maize (Zea mays L.), sorghum [Sorghum bicolor (L.) Moench.] and pearl millet (Pennisetum glaucum L.) with 0, 50, 75 and $100 \%$ of their respective recommended dose of $\mathrm{N}$ (RDN) levels. The highest gross returns, net returns, B: C ratio and soybean equivalent yield (SEY) were observed under soybean+maize intercropping system along with $100 \% \mathrm{RDN}$ to intercropped maize in both the years of experimentation. Among the intercropping systems, soybean+maize intercropping systems recorded higher returns and SEY than others (Layek, J., Shivakumar et al. 2015). Soybean grown under soybean-wheat-mungbean system had significantly higher total uptake $\mathrm{N}$ and $\mathrm{K}$ over soybean-wheat-fallow system. Application of $25 \%$ RDF + 50\% RDN through FYM along with Rhizobium and PSB gave significantly highest pods/plant, seeds/pod and seed and stover yields of soybean over control during both the years of study. Application of 50\% RDF + 25\% RDN thorough FYM + biofertilizers or $25 \%$ RDF + 50\% RDN through FYM + biofertilizers, remaining on par with each other fetched maximum net returns. Significantly maximum total uptake of $\mathrm{N}$ and $\mathrm{P}$ were recorded with the application of 25\% RDF + 50\% RDN thorough FYM + biofertilizers over control (Prajapat, K., Vyas, A. K., Dhar, Shiva, 2015. Impact of short-term zero tillage is short lived for favourable soil health and root parameters when skipping with conventional tillage Rajkumar, Singh, Karunakaran, V., 2015)

The water requirement of soybean and wheat estimated by Penmann-Monteith method was in close agreement $(-2.58 \%$ and $9.26 \%$ deviation) with the measured average water requirement (401.6 and $352.2 \mathrm{~mm}$ ) respectively followed by Hargreaves method for Bhopal district. It is also inferred that in absence of solar radiation data Hargreaves method could be considered for predicting water requirement of soybean and wheat crops. These water requirement values are useful for effective planning of irrigation scheduling of the soybean and wheat crops in the State (Singh, Ramadhar, Singh, Karan, Bhandarkar, D. M.,2015). Sharma, Mahaveer P. (2015) IP of resident AM fungi in soybean rotation involving maize in conservation tillage was found to be highly correlated ( $\mathrm{r}=0.96$ to 0.99 ) with grain yield of soybean and maintaining higher organic carbon which indicates the functioning of resident AM fungi in enhancing the soybean yield. The seasonal average $G$ was $13.1 \%, 15.2 \%, 10.9 \%$, and $12.8 \%$ of $\mathrm{R}(\mathrm{n})$ for irrigated maize, rainfed maize, irrigated soybean, and rainfed soybean, respectively. Statistical analyses of the performance of the four models showed a wide range of variation in $G$ estimation. The root mean square error (RMSE) of

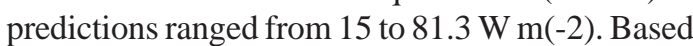
on the wide range of RMSE, it is recommended that local calibration of the models should be 
carried out for remote estimation of soil heat flux (Irmak, A., et al. 2011).

Soybean Glycine max (L) Merr. yield, irrigation water use efficiency, crop water use efficiency and soil water extraction response to treatments of full, limited, or delayed irrigation versus a rainfed control were investigated using a subsurface drip irrigation system. This researches demonstrated that delaying the onset of irrigation until the and practicing full irrigation thereafter for soybean grown on silt loam soils resulted in yields.

\section{MATERIALSANDMETHODS}

The objectives were solved by setting up and carrying out one-factorial and multiple-factorial field experiments on a demonstration site of the Distribution Center "Ushkonyr" of the Kazakh Scientific Research Institute of agriculture and plant growing, table 1.

The total area of the experiment - 0,15 hectares. The area of land plots is $40-50$ sq.m, 3 replications.

a) Phenological observation over growth and development of plants in the main phases by variety control technique of State commission (Balashev, 1968);

b) Studying of water and physical and meliorative properties of the soil (Kachinsky N. A. Physics soil. Chapter II. Water physical properties and modes of the soil. Moscow, the Higher school, 1970).

c) Costing of field germinating ability by calculation made on 4 fixed sites with 0,25 sq.m on all land plots at full shoots (Balashov, 1968);

d) Costing of density of plant standing by calculation of quantity of plants with 1 sq.m of a land plot at the beginning and the end of vegetation of the studied cultures in twofold replications.

e) Costing of accumulation dynamics of biomass of plants of the studied cultures in the main phases of their development by selection of plants with 1 sq.m of each land plot in twofold replications with measurement of wet and dry weight. (The guide to control and observe phases of agricultural development, 1982, p. 150);

f) Water consumption of rice plants was defined by a balance method.

g) Costing of crop contamination, vulnerability and damageability by pests is carried out according to standard methods (Methodical instructions on monitoring of number of weed plants, pests and development of diseases, Astana, 2004);

h) Sampling for studying of the maintenance of nutritious elements in the soil and plants will be carried out in the main rice growth and development phases.

i) Before harvesting from three experiment replications, sheaf samples from 1 sq.m were selected. Basic elements of structure of rice crop (quantity of plants, quantity of the general and productive stalks, mass of a sheaf, amount of grains in a panicle, the mass of 1000 grains) are determined according to variety control technique of State commission (Balashev, 1968);

Costing of a crop is carried out by the SAMPO-250 combine;

k) Processing of crop data according to Dospekhov's technique, [1985];

l) Quality of grain according by the technique stated in the reference book "Assessment of grain quality”, M. VO “Agropromizdat”, 1987;

m) Studying of agrochemical properties of soil by a technique of agrochemical researches ${ }^{27-}$ 33 .

n) Calculation of economic efficiency is made on the actual costs of unit of the made production from area's hectare according to the actual monetary and energy costs of cultivation of the studied cultures.

\section{Drip irrigation system}

Drip irrigation system includes:

a) Accumulator of irrigation water on $36 \mathrm{~m} 3$ near the Kaskelenka river (figure 1).

b) The water pump Pedrollo F 32/200B with a productivity of $50 \mathrm{~m} 3 /$ an hour.

c) A clarifier on $25 \mathrm{~m} 3$ at the height of low level of $5 \mathrm{~m}$.

d) Sand strainer (figure 2)

e) Cleaning strainer

f) An injector for additional fertilizing

g) Main pipes

h) Delivery pipes

i) Irrigation tapes with drippers for surface drip 
irrigation

j) Irrigation pipes with drippers for subsurface drip irrigation

\section{Agrotechnical conditions}

The general agrotechnology for drip irrigation soil preparation was in the following:

a) Fall-plowing on depth of 25-27 cm.

b) Current planning.

c) Early-spring braking.

d) Introduction of phosphoric fertilizers for background creation.

e) Cultivation on depth of 12-15 cm.

f) Preseeding processing on depth of seed crops.

f) Crops of rice are made by a seeder 2BMJ-4 (People's Republic of China) which carries out simultaneous laying of a drop tape, a tension of the mulching film, seal of seeds over a film and a packing with the soil filling (figure 3).

h) Norm of seeding is $15-30 \mathrm{~kg} /$ hectare depending on ways of crops.

i) Additional fertilizing was made by ammonium nitrate with irrigation water of a drip irrigation according to schemes of experiences: the first - at the beginning of tillering, the second - in a phase of a full tillering, the third - in a booting phase, the fourth - in an ear emergence phase, the fifth - in a phase of dairy ripeness of grain.

Harvesting was carried out by direct combining SAMPO-250 (figure 6).

\section{RESULTSAND DISCUSSION}

As a result of research, growth and development, formation of a harvest of soy plants in many ways depended on the studied ways of drip irrigation and ways of protection from weeds, levels of mineral nutrition (table 2). Soy shoots, on options with the mulching film, appeared on 5-7 days earlier than the option without the film. They advanced in growth and development in early phases, a ternate leaf, branching, budding eventually were reflected in formation of biomass and a harvest.

The amount of weeds on soy crops at the beginning of vegetation was 146-176 pieces on one square meter. Mechanical treatment led to decrease in quantity of weeds to 44-56 pieces, and chemical processing - up to 33-42 pieces (table 3).

The most effective way for protection from weeds on soy crops was drip irrigation under the mulching film where the amount of weeds at the beginning of vegetation did not exceed 36-44 pieces/sq.m.

In table 4 there is data on accumulation dynamics of biomass of plants in the main phases of its growth.

You can clearly see positive influence of the mulching film on accumulation of biomass of soy plants, especially in comparison with subsurface way of drip irrigation. Crude mass reaches $4222 \mathrm{~g}$ and 2694 without mulching. Unlike in year 2013, there is a higher efficiency of subsurface drip irrigation on formations of biological harvest.

As it is noticeable from table 5, the soy plant with drip irrigation forms rather high leaf

Table 1. Study of ways of soy grades drip irrigation

\begin{tabular}{lll}
\hline S.N & Ways of drip irrigation & Soybean sort \\
\hline 1 & Furrow irrigation & Zhalpaksay \\
2 & Surface drip irrigation & Zhansaya \\
3 & Surface drip irrigation under & \\
& mulch film & Lastochka \\
4 & Subsurface drip irrigation & Vita \\
5 & Subsurface drip irrigation & \\
& under mulch film & Dikovit
\end{tabular}

Table 2. Phenology of soy development depending on ways of drip irrigation

\begin{tabular}{lccccc}
\hline Ways of drip irrigation & Shoots & ternate leaf & branching & $\begin{array}{c}\text { blossoming } \\
\text { of beans }\end{array}$ & $\begin{array}{c}\text { Formation } \\
\text { of }\end{array}$ \\
\hline Furrow irrigation & 20.05 & 20.06 & 02.07 & 27.07 & 04.08 \\
Surface drip irrigation & 19.05 & 20.06 & 02.07 & 27.07 & 05.08 \\
Surface drip irrigation under mulching film & 17.05 & 17.06 & 30.06 & 25.07 & 02.08 \\
Subsurface drip irrigation & 20.05 & 20.06 & 03.07 & 27.07 & 06.08 \\
Subsurface drip irrigation under mulching film & 18.05 & 18.06 & 01.07 & 26.07 & 03.08 \\
\hline
\end{tabular}


surface of 40,6-70,6 square meters on one hectare. Efficiency of a surface way of an irrigation can be seen on formation of a leaf surface, not like in the option with subsurface drip irrigation. Drip irrigation with mulching film had the highest results, and that remains for the entire period of vegetation of plants.

Table 3. A contamination of soy crops depending on ways of drip irrigation and ways of protection from weeds

\begin{tabular}{|c|c|c|c|c|c|}
\hline \multirow[t]{2}{*}{ Ways of drip irrigation } & \multicolumn{4}{|c|}{ The amount of weeds, piece/sq.m, } & \multirow[t]{2}{*}{ Weed types } \\
\hline & $\begin{array}{l}\text { Phase of } \\
\text { ternate leaf }\end{array}$ & $\begin{array}{l}\text { The amount } \\
\text { mechanical }\end{array}$ & $\begin{array}{l}\text { of weeds, } \mathrm{P} \\
\text { chemical }\end{array}$ & $\begin{array}{l}\text { iece/sq.m, } \\
\text { mulching }\end{array}$ & \\
\hline Furrow irrigation & 154 & 25 & 36 & - & \multirow{5}{*}{$\begin{array}{l}\text { Yellow foxtail, } \\
\text { corobind, } \\
\text { bristle grass, } \\
\text { redroot, } \\
\text { clotbur, } \\
\text { dindle etc. }\end{array}$} \\
\hline Surface drip irrigation & 162 & 26 & 22 & - & \\
\hline Surface drip irrigation under mulching film & 25 & - & - & 14 & \\
\hline Subsurface drip irrigation & 132 & 24 & 33 & - & \\
\hline Subsurface drip irrigation under mulching film & 24 & - & - & 21 & \\
\hline
\end{tabular}

Table 4. Accumulation of crude biomass of soy plants depending on ways of drip irrigation

\begin{tabular}{lccccc}
\hline \multirow{2}{*}{ Ways of drip irrigation } & \multicolumn{4}{c}{ Crude biomass of plants, h/10 plants } \\
\cline { 2 - 6 } & ternate leaf & branching & budding & $\begin{array}{c}\text { Formation } \\
\text { of beans }\end{array}$ & $\begin{array}{c}\text { Grain } \\
\text { filling }\end{array}$ \\
\hline Surface drip irrigation & & & & & \\
Surface drip irrigation under mulching film & 106 & 520 & 980 & 1400 & - \\
Subsurface drip irrigation & 146 & 310 & 1540 & 3130 & - \\
Subsurface drip irrigation under mulching film & 176 & 490 & 2010 & 4100 & - \\
\hline
\end{tabular}

Table 5. Accumulation of crude biomass of soy grades with drip irrigation

\begin{tabular}{|c|c|c|c|c|c|}
\hline \multirow[t]{2}{*}{ Ways of drip irrigation } & \multicolumn{5}{|c|}{ Crude biomass of plants, $\mathrm{h} / 10$ plants } \\
\hline & ternate leaf & branching & budding & $\begin{array}{l}\text { Formation } \\
\text { of beans }\end{array}$ & $\begin{array}{l}\text { Grain } \\
\text { filling }\end{array}$ \\
\hline Zhalpaksay & 166 & 660 & 1920 & 2400 & - \\
\hline Zhansaya & 210 & 480 & 1980 & 3640 & - \\
\hline Lastochka & 167 & 510 & 2040 & 5560 & - \\
\hline Vita & 204 & 520 & 1120 & 2520 & - \\
\hline Dikovit & 176 & 540 & 2140 & 4520 & - \\
\hline
\end{tabular}

Table 6. Leaf surface of soy grades with drip irrigation

\begin{tabular}{|c|c|c|c|c|}
\hline \multirow[t]{2}{*}{ Grades } & \multicolumn{4}{|c|}{ Areal of soy leaves Sq.m/10 plants } \\
\hline & ternate leaf & branching & budding & Formation of beans \\
\hline Zhalpaksay & 0,26 & 1,75 & 5,12 & 7,17 \\
\hline Zhansaya & 0,40 & 1,27 & 9,20 & 14,30 \\
\hline Lastochka & 0,34 & 1,35 & 9,90 & 20,76 \\
\hline Vita & 0,34 & 1,38 & 4,70 & 8,82 \\
\hline Dikovit & 0,39 & 1,43 & 10,10 & 19,12 \\
\hline
\end{tabular}


Table 7. Soy harvest structure depending on ways of drip irrigation, 2014

Ways of drip irrigation

\begin{tabular}{ccccc}
$\begin{array}{c}\text { Amount of } \\
\text { plants, } \\
\text { piece/sq.m }\end{array}$ & $\begin{array}{c}\text { Amount of } \\
\text { branches, } \\
\text { piece }\end{array}$ & $\begin{array}{c}\text { Amount of } \\
\text { beans in 1 } \\
\text { plant, piece }\end{array}$ & $\begin{array}{c}\text { Mass 1000 } \\
\text { grains, g }\end{array}$ & $\begin{array}{c}\text { Biological } \\
\text { harvest, } \\
\text { h/sq.m }\end{array}$ \\
20 & 8,0 & 52 & 146 & 467 \\
22 & 12,4 & 78 & 156 & 739 \\
20 & 8,8 & 46 & 150 & 422 \\
21 & 10,8 & 69 & 160 & 664 \\
\hline
\end{tabular}

Table 8. Structure of the harvest of soy grades under drip irrigation, 2013-2015.

\begin{tabular}{lccccc}
\hline Surface drip irrigation & 20 & 8,0 & 52 & 146 & 467 \\
Surface drip irrigation under mulching film & 22 & 12,4 & 78 & 156 & 739 \\
Subsurface drip irrigation & 20 & 8,8 & 46 & 150 & 422 \\
Subsurface drip irrigation under mulching film & 21 & 10,8 & 69 & 160 & 664 \\
\hline
\end{tabular}

\begin{tabular}{lccccc}
\hline Grades & $\begin{array}{c}\text { Amount of } \\
\text { plants, } \\
\text { piece/sq.m }\end{array}$ & $\begin{array}{c}\text { Amount } \\
\text { of branches, } \\
\text { piece }\end{array}$ & $\begin{array}{c}\text { Amount of } \\
\text { beans in 1 } \\
\text { plant, piece }\end{array}$ & $\begin{array}{c}\text { Mass } \\
1000 \\
\text { grains, g }\end{array}$ & $\begin{array}{c}\text { Biological } \\
\text { harvest, } \\
\text { h/sq.m }\end{array}$ \\
\hline Zhalpaksay & $20 \pm 2,2$ & $8,2 \pm 0,9$ & $52 \pm 14,5$ & $146 \pm 0,9$ & $467 \pm 19,8$ \\
Zhansaya & $20 \pm 2,9$ & $9,4 \pm 1,4$ & $76 \pm 17,8$ & $145 \pm 0,7$ & $660 \pm 20,6$ \\
Lastochka & $20 \pm 3,5$ & $8,8 \pm 1,2$ & $84 \pm 11,6$ & $150 \pm 1,8$ & $760 \pm 17,9$ \\
Vita & $20 \pm 2,7$ & $10,1 \pm 2,3$ & $68 \pm 16,9$ & $150 \pm 1,6$ & $620 \pm 21,8$ \\
Dikovit & $20 \pm 3,0$ & $12,4 \pm 3,4$ & $78 \pm 13,2$ & $156 \pm 2,1$ & $739 \pm 13,5$ \\
\hline
\end{tabular}

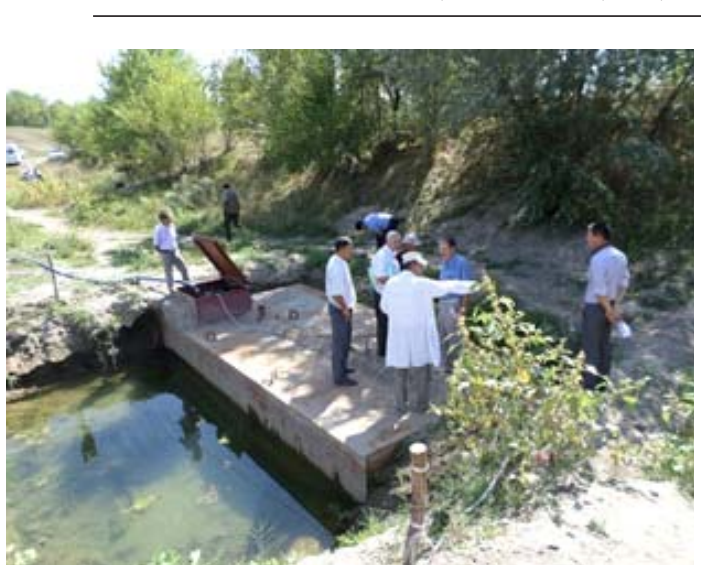

Fig. 1. Water intake system for drip irrigation

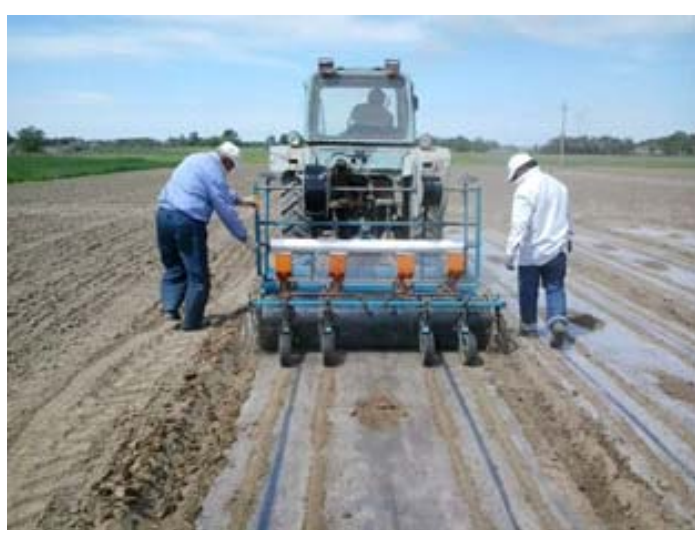

Fig. 3. Double-row rice sowing with laying of both irrigation tape and tensioning of the film

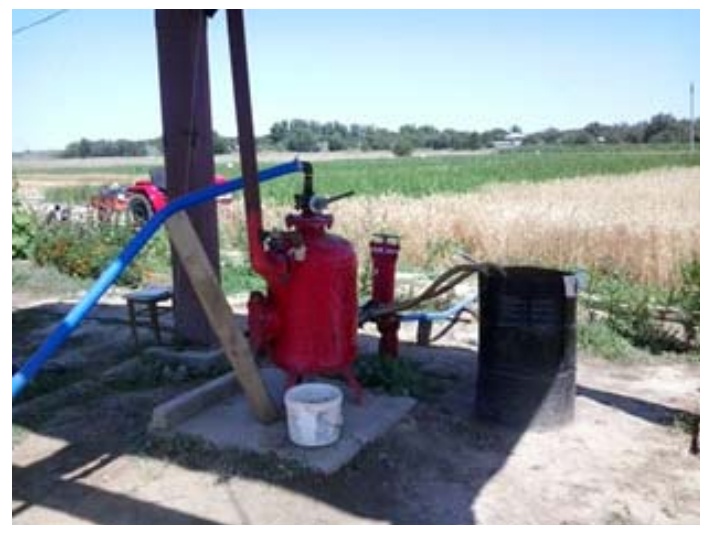

Fig. 2. Water cleaning and additional fertilizing system

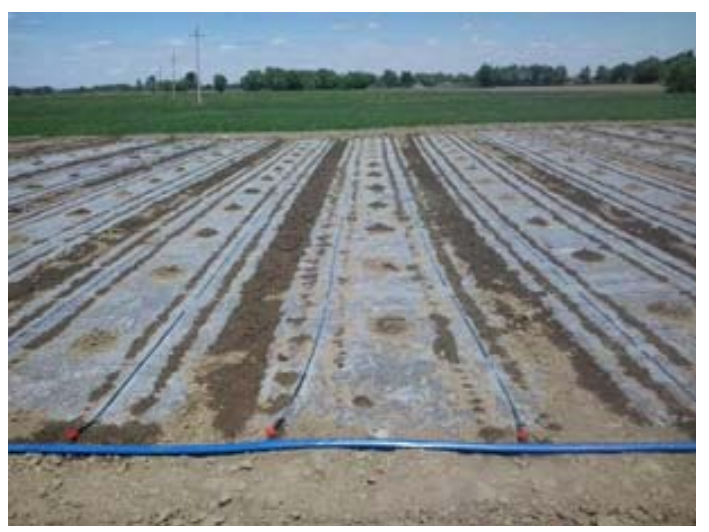

Fig. 4. Drip irrigation system 
Plants from the option with the mulching film had a healthy appearance, a powerful leaf blade and differed in dark green colors of leaves which characterizes good conditions of cultivation (table 6 , figures 7,8 ).

Intensive growth and development of plants in the option with the mulching film under

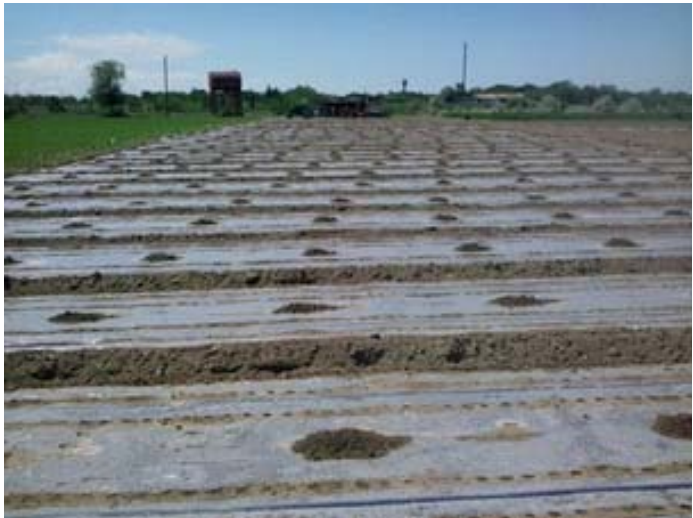

Fig. 5. Look of the experiment field after seeding

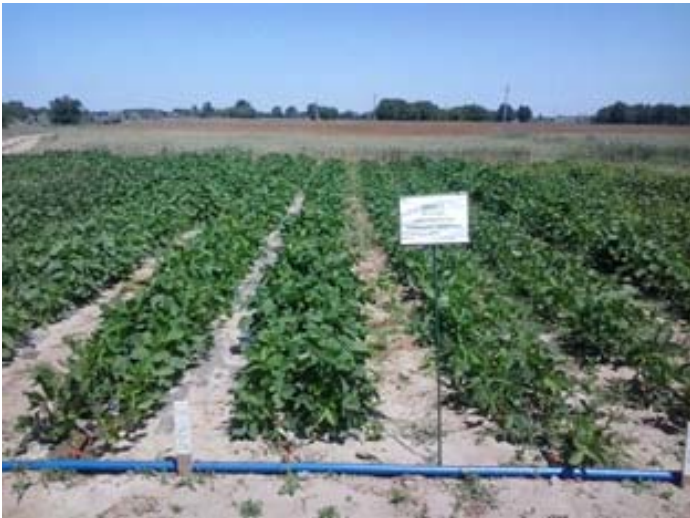

Fig. 5-6. State of soy planting

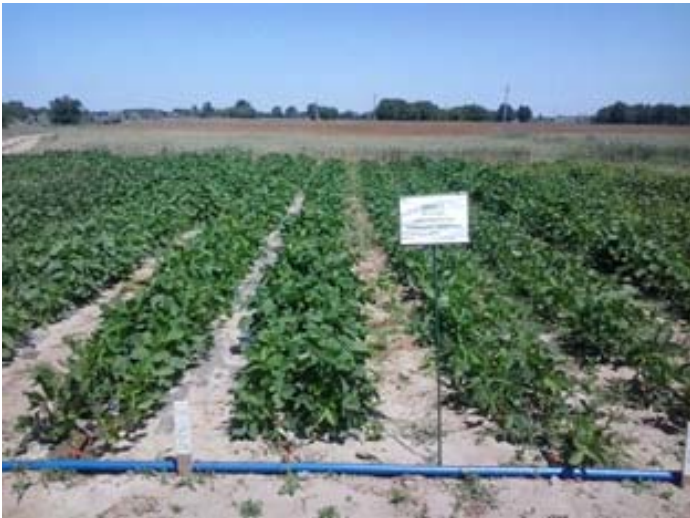

Fig. 7. Soy at the beginning of vegetation drip irrigation during vegetation, eventually, reflected in good branching, formation of more beans in a plant and the absolute mass of grain.

Analyses results of soy harvest structure show (table 7) that height of stalks in option of surface drip irrigation with the mulching film reaches $107 \mathrm{~cm}$, with a height of $77 \mathrm{~cm}$ without the

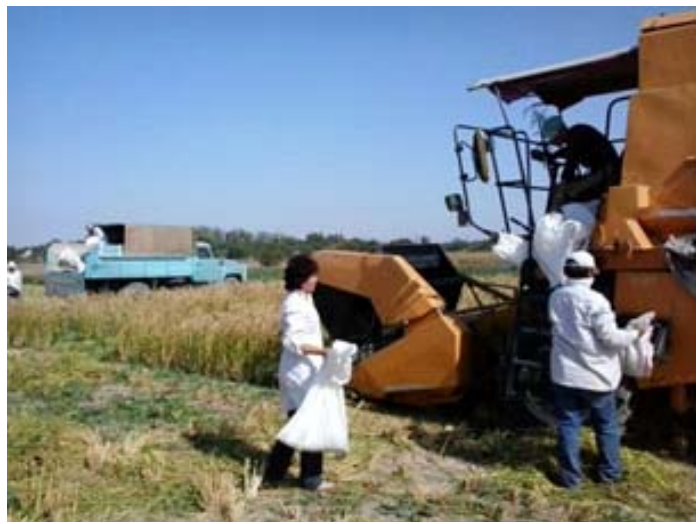

Fig. 6. Plot costing of harvesting with a combine
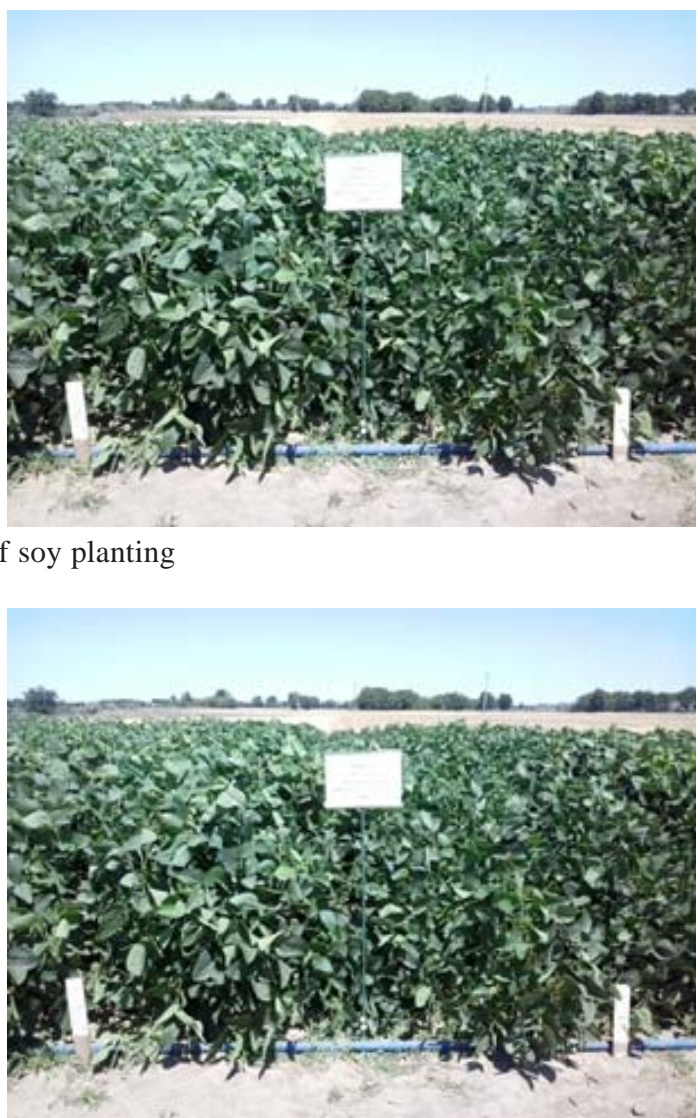

Fig. 8. Soy in the phase of budding 
mulching film. Ways of drip irrigation have significant effect on formation of separate elements of the harvest structure. So, use of the mulching film under drip irrigation increases quantity of branches on 1-2,4 units, quantity of beans in one plants from 37 to 49 pieces, the absolute mass of grains on 24-32 g.

Intensive growth and development of soy plants during vegetation with formation of bigger biomass of plants, a leaf surface and basic elements of harvest structure eventually led to formation of more crops. It should be noted that the bigger soy harvest was in option with surface drip irrigation on 3,6-9,2 c/hectare. Despite the bad weather conditions for growth and development of soy in the southeast of Kazakhstan, we have got a big crop (42,2 c/hectare) in option with use of the mulching film (table 7). At the same time the most effective way of drip irrigation was the surface one.

As a result of research, there has been revealed the most acceptable option of cultivation and irrigation for the Kazakhstan soy gradessurface drip irrigation with the mulching film, table 8, and also the grades Lastochka and Dikovit showed the highest results in harvest in three years.

\section{CONCLUSION}

Field experiments have proved that of use mulch under drip irrigation makes it possible to obtain that high yield and nutritional value of soybeans, increasing the efficiency of water use, reducing moisture permeation is the root zone, reduce evaporation from the soil surface, rational distribution of moisture, effective distribution of fertilizer, reducing plant water stress due to frequent watering, and as a result of the high quality of the product, saving energy. Comparison of the productivity of soybean varieties showed that productivity in variants with mulch far exceeded variants without mulching.

\section{REFERENCES}

1. Dogan, Ergun, Kirnak, Halil, Copur, Osman. Effect of seasonal water stress on soybean and site specific evaluation of CROPGRO-Soybean model under semi-arid climatic conditions. Agricultural Water Management. 2007; 90(12): 56-62.

2. Gercek, Sinan, Boydak, Erkan, Okant, Mustafa,
Dikilitas, Murat. Water pillow irrigation compared to furrow irrigation for soybean production in a semi-arid area. Agricultural Water Management.2009; 96(1): 87-92

3. Grabow, G. L., Huffman, R. L., Evans, R. O. SDI Dripline Spacing Effect on Corn and Soybean Yield in a Piedmont Clay Soil. Journal of Irrigation and Drainage Engineering-Asce. 2011; 137 (1): 27-36.

4. H. Kirnak, E. Dogan, H. Turkoglu. Effect of drip irrigation intensity on soybean seed yield and quality in the semi-arid Harran plain, Turkey. Spanish Journal of Agricultural Research 2010; 8(4):1208-1218.

5. Hunt, P. G., Stone, K. C., Matheny, T. A. Double-Cropped Soybean and Wheat with Subsurface Drip Irrigation Supplemented by Treated Swine Wastewater. Communications in Soil Science and Plant analysis. 2011; 42(22): 2778-2794

6. Irmak, A., Singh, R. K., Walter-Shea, E. A. Comparison and analysis of empirical equations for soil heat flux for different cropping systems and irrigation methods. Transactions of the Asabe. 2011 ; 54(1): 67-80.

7. Irmak, S. ,Specht, J. E., Odhiambo, L. O., Rees, J. M., Soybean Yield, Evapotranspiration, Water Productivity, And Soil Water Extraction Response To Subsurface Drip Irrigation and Fertigation //Transactions of the Asabe. 2014; 57(3 ): 729-748

8. Kanaan, Bassam Abdul Jabbar, Saud, Halimi Mohd, Othman, Radziah. Influence of molybdenum in association with rhizobium on enhanced biological nitrogen fixation, growth and yield of soybean under drip irrigation system. Legume Research.2013; 36(6): 522-527.

9. Karunakaran, V., Behera, U. K., Influence of sequential tillage and residue management practices on soil and root parameters in soybean (Glycine max) - wheat (Triticum aestivum) cropping system. Indian Journal of Agricultural Sciences. 2015; 85(2) : 182-188.

10. Kirkova, Y., Irrigation regime effect on soil and plants.. Journal of Environmental Protection and Ecology. 2010; 11(2): 577-585.

11. Layek, J., Shivakumar, B. G., Rana, D. S., Munda, S., Performance of soybean (Glycine max) intercropped with different cereals under varying levels of nitrogen. Indian Journal of Agricultural Sciences. 2015; 85(12): 1571-1577.

12. Miyauchi, Yosuke, Isoda, Akihiro, Li, Zhiyuan, Wang, Peiwu. Soybean Cultivation on Desert Sand Using Drip Irrigation with Mulch. Plant Production Science. 2012; 15(4): 310-316

13. Odhiambo, L. O., Irmak, S., Relative 
Evaporative Losses and Water Balance in Subsurface Drip and Center Pivot-Irrigated Soybean Fields. Journal îf Irrigation ànd Drainage Engineering 2015; 141(11)

14. Omotayo B Adeboye., Bart Schultz., Kenneth O., Adekalu and Krishna Prasad., Crop water productivity and economic evaluation of drip irrigated soybeans (Glyxine max L. Merr.)// Adeboye et al. Agric \& Food Secur 2015; 4(10):214.

15. Prajapat, K., Vyas, A. K., Dhar, Shiva., Effect of cropping systems and nutrient management practices on growth, productivity, economics and nutrient uptake of soybean (Glycine max). Indian Journal of Agricultural Sciences. 2015; 85(9): 1138-1143

16. Rajkumar, Singh, Devvrat, Murlidharan, Pooja. Lodging in soybean (Glycine max) as influenced by growth habit and other traits. Indian Journal of Agricultural Sciences. 2014; 84(7) : 896-898.

17. Ramteke, Rajkumar, Murlidharan, Pooja., Characterization of soybean (Glycine max) varieties as per DUS guidelines. Indian Journal of Agricultural Sciences. 2012; 82(7): 572-577

18. Sharma, Mahaveer P., Gupta, Sonam, Sharma, Sushil K., Effect of tillage and crop sequences on arbuscular mycorrhizal symbiosis and soil enzyme activities in soybean (Glycine max) rhizosphere. Indian Journal of Agricultural Sciences. 2015; 82(1): 25-30

19. Singh, Ramadhar, Singh, Karan, Bhandarkar, D. M., Estimation of water requirement for soybean (Glycine max) and wheat (Triticum aestivum) under vertisols of Madhya Pradesh. Indian Journal of Agricultural Sciences. 2015; 84(2): 190-197.

20. Skaggs, K. E., Irmak, S., Characterization of nighttime evapotranspiration and other surface energy fluxes and interactions with microclimatic variables in subsurface drip and center-pivot irrigated soybean fields. Transactions of the asabe. 2011; 54(3) : 941-952.

21. Vamerali, T., Barion, G., Hewidy, M., Mosca, G., Soybean isoflavone patterns in main stem and branches as affected by water and nitrogen supply. European journal of agronomy. 2012; 41: $1-10$ 